\title{
Protolitic Equilibria and Stability Constants of Mn (II) and Ni (II) Complexes of 3-formylpyridine Thiosemicarbazone in Sodium Dodecyl Sulphate(SDS)- Water Mixture
}

\author{
Dunkana Negussa Kenie ${ }^{1^{*}}$ and Satyanarayana $A^{2}$ \\ ${ }^{1}$ Department of Chemistry, College of Computational and Natural Sciences, Wollega University, \\ P.O Box: 395, Nekemte, Ethiopia \\ ${ }^{2}$ Department of Physical and Nuclear Chemistry and Chemical Oceanography, Andhra University, \\ Visakhapatnam -530003 , India
}

\begin{tabular}{|c|c|}
\hline Abstract & Article Information \\
\hline \multirow{5}{*}{$\begin{array}{l}\text { Protonation constant of nicotinaldehyde thiosemicarbazone (NTSC) and its complexation } \\
\text { with } \mathrm{Mn} \text { (II) and } \mathrm{Ni} \text { (II) were studied in SDS-water }(1.15 \% \mathrm{w} / \mathrm{v}) \text { mixture at } 303 \mathrm{~K} \text { under } \\
\text { nitrogen atmosphere and an ionic strength of } 0.1 \mathrm{~mol} \mathrm{dm}^{-3} \mathrm{pH} \text {-potentiometrically. The } \\
\text { protonation constant of the ligand and stability constant of its } \mathrm{Mn} \text { (II) and Ni (II) complexes } \\
\text { were calculated by using MINIQUAD } 75 \text { computer program, and species distribution } \\
\text { diagrams were produced using the HySS computer program. Selection of the best fit } \\
\text { chemical models is based on statistical parameters. The predominant species detected for } \\
\text { both metals for } 1: 1 \text { and } 1: 2 \text { ratios were } \mathrm{ML}, \mathrm{MLH} \mathrm{ML}_{2}, \mathrm{ML}_{2} \mathrm{H} \text {, and } \mathrm{ML}_{2} \mathrm{H}_{2} \text { respectively. The } \\
\text { appropriateness of experimental conditions is verified by introducing errors deliberately in } \\
\text { the concentrations of ingredients of the solution. Distribution diagram and plausible } \\
\text { equilibria for the formation and possible structure of the complex species are also } \\
\text { presented. }\end{array}$} & 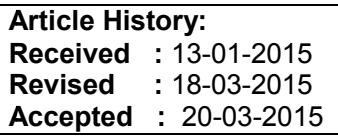 \\
\hline & $\begin{array}{l}\text { Keywords: } \\
\text { Protonation constant } \\
\text { Stability constant } \\
\text { Complex equilibria } \\
\text { SDS }\end{array}$ \\
\hline & *Corresponding Author: \\
\hline & Dunkana Negussa Kenie \\
\hline & $\begin{array}{l}\text { E-mail: } \\
\text { dunkana11@yahoo.com }\end{array}$ \\
\hline
\end{tabular}

\section{INTRODUCTION}

Transition metal complexes of thiosemicarbazone have been receiving considerable attention largely of chemists and pharmacologists because of their wide range of biological and carcinostatic activities: antibacterial, antifungal, antiviral and anti-inflammatory agents (Beraldo and Gambino, 2004), antitumour, anticancer, and anti-HIV (Chandra and Kumar, 2007). They are also considered as excellent analytical reagents used in gravimetric and spectrophotometric determinations (Enyedy, 2010). They are interestingly promising in their use against cancer because of their selectivity. The main known effects related to their anticancer activity (Enyedy, 2011) are ribonucleotide reductase (RR) inhibition (Brockman et al., 1970), reactive oxygen species (ROS) production(Shao et al., 2006), topoisomerase II inhibition (Hall et al., 2000), mitochondria disruption (Yuan et al., 2004), and, more recently, a multidrug resistance protein (MDR1) inhibition (Ludwig et al., 2006 and Wu et al., 2007 ).

Although the free ligands of thiosemicarbazones showed interesting biological activity, transition metal complexes revealed greater biological activity (Pelosi, 2010; John et al., 2004; Belicchi-Ferrari et al., 2005; Gulea et al., 2004; Birca et al., 2004). And also studies made known that the metal complexes exert differential activity against the organisms' studied (Williams, 1972). This indicates that coordination to the metal activates the biologically active ligand and the metal serves to trigger the biologically active thiosemicarbazone ligand. Still the activity of the thiosemicarbazones is affected by the type and kind of substituent to the thiosemicarbazone moeity (Liberta and West, 1992). The coupling of thiosemicarbazones with metals, gives good biological activity due to the synergistic effect.

In solution thiosemicarbazones are known to exist in thiol form tautomerizing from the thione form. Complexation usually takes place via dissociation of the acidic proton, resulting in the formation of usually fourmembered or depending on the alkyl/aryl group a fivemembered chelate ring (Pal et al., 2002). Nicotinaldehyde thiosemicarbazone (NTSC) is used as anti tubercular drug combined with isoniazid (isonicotinic acid hydrazide, INH) (Grunberg and Leiwant, 1951). To understand the transport of thiosemicarbazone complexes in vivo it is essential to report the solution phase complexation of this ligand with some of the essential metal ions [Mn (II) and $\mathrm{Ni}$ (II)]. Thus, in this study the protonation constant of NTSC and its stability constant with Mn (II) and Ni (II) is reported and also the possible structures of the complexes are proposed. 


\section{MATERIALS AND METHODS}

\section{Reagent and Apparatus}

Chlorides of $\mathrm{Mn}$ (II) and Ni (II), EDTA disodium dehydrate, sodium hydroxide pellets, potassium hydrogen phthalate (KHP) and oxalic acid were purchased from E.Merck.Pro.analysi. Nicotinaldehyde thiosemicarbazone (NTSC) was supplied by Fluka, AR and Sodium chloride was obtained from B.D.H.AnalaR. All reagents were analytical grade.

Stock solution of $\left(0.1\right.$ mole $\left.\mathrm{dm}^{-3}\right)$ chloride of $\mathrm{Mn}$ (II) and $\mathrm{Ni}$ (II) was prepared with slight acidification to repress the hydrolysis of the metal ion(Baes Jr. and Mesmer, 1976) in deionized water and standardized complexometerically with EDTA(Birk, J.P. 1970). A 0.05 mole $\mathrm{dm}^{-3}$ solution of NTSC was prepared freshly just before the titrations in $0.10 \mathrm{~mol} \mathrm{dm}^{-3} \mathrm{HCl}$. The solutions of sodium hydroxide, potassium hydrogen phthalate and sodium chloride were prepared as reported elsewhere. The $\mathrm{NaOH}$ solution was standardized with oxalic acid solution $\left(0.05\right.$ mole $\left.\mathrm{dm}^{-3}\right)$

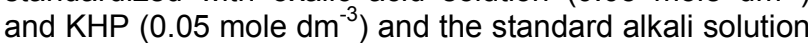
was again used for the standardization of $\mathrm{HCl}$. The strength of the prepared carbonate-free sodium hydroxide solution was determined by titrating it against hydrochloric acid solution using the Gran plot method(Gran, G 1988).

The $\mathrm{pH}$-metric titrations were carried out with a Control Dynamics $\mathrm{pH}$ meter model APX $175 \mathrm{E} / \mathrm{C}$ in conjunction with a 0-14 pH range a combined glass calomel electrode. The $\mathrm{pH}$ meter was standardized before each titration with standard buffer solutions of $\mathrm{pH} 4.00,7.00$, and 9.00. A tip less double walled Pyrex glass vessel of $100 \mathrm{ml}$ capacity fitted with a Perspex lid, through which the glass calomel electrode, gas inlet and out let tubes and burette tip were admitted, was used for carrying out the potentiometric titrations and the test solution was degasified with nitrogen gas. The temperature of the solution was maintained by passing water from a thermostat through the annular space between the walls of the titration cell.

\section{Data Acquisition and analysis}

Calvin-Wilson titration technique modified by Rossotti (Irving and Rossotti, 1953 and 1954) was employed for the study of protonation and complex equilibria of the ligand. Requisite volumes of hydrochloric acid (to give an overall concentration of $2.0 \times 10^{-2}$ mole. $\mathrm{dm}^{-3}$ ), sodium chloride (ionic strength was maintained at 0.1 mole. $\mathrm{dm}^{-3}$ ), ligand solution in SDS-water $(1.15 \% \mathrm{w} / \mathrm{v})$ in the presence and absence of metal ions in a total volume of $50 \mathrm{~cm}^{3}$ was titrated with $\sim 0.2$ mole. $\mathrm{dm}^{-3}$ sodium hydroxide at $303 \mathrm{~K}$. The concentration of the ligand was 0.005 to 0.015 mol. $\mathrm{dm}^{-3}$ in different experiments. The same titrations were repeated in the presence of metal ion at 1:1, and 1:2 ratios of initial concentrations of metal to ligand. All the titrations are performed in triplicate by changing the concentrations of ligand to metal ratio in the total initial volume. After addition of each aliquot $(0.1 \mathrm{ml})$ of sodium hydroxide, the $\mathrm{pH}$ - meter dial reading was recorded at regular intervals of time until two successive readings do not differ in more than $0.01 \mathrm{pH}$ units. The titrations were performed up to a $\mathrm{pH}$ of $\sim 12.0$. In some of the titrations, the upper $\mathrm{pH}$ limit for rejecting data was determined by the appearance of opalescence leading to precipitation.

For a system containing a metal ion and a ligand forming $\mathrm{N}$ complexes, the formation of a complex can be represented as,

$$
m . \mathrm{M}+\mathrm{l} . \mathrm{L}+h \mathrm{H} \rightleftharpoons \mathrm{M}_{m} \mathrm{~L} / \mathrm{H}_{h}
$$

and the overall formation constant is given by,

$$
\beta_{m / h}=\left[\mathrm{M}_{m} \mathrm{~L}, \mathrm{H}_{h}\right]_{\mathrm{i}} /[\mathrm{M}]_{\mathrm{i}}^{m} \cdot[\mathrm{L}]_{\mathrm{i}}^{l} \cdot[\mathrm{H}]_{\mathrm{i}}^{h}
$$

Where $[\mathrm{M}]_{i},[\mathrm{~L}]_{\mathrm{i}}$ and $[\mathrm{H}]_{\mathrm{i}}$ are the free concentrations of metal, ligand and hydrogen ion respectively at $i^{\text {th }}$ experimental point. Different species in solution possess different values of stoichiometric coefficients $m, l$ and $h$. Positive value of $h$ indicates protonated species and negative value indicates either deprotonated or hydroxylated species. Several computer programs have been proposed for the evaluation of both stoichiometric coefficients and formation constants for all the species present in solution. Most of these algorithms are based on the minimization of error square sum $(U)$ between the experimentally determined quantities and the corresponding calculated ones using the estimated values of the formation constants. The values of the formation constants obtained by graphical procedures are taken as initial estimates. The computer based algorithms generate a vector of shifts to the formation constants and free concentrations. The modified constants after applying the shifts are then used as the initial estimates for the next cycle. If the chosen model is a true representation of the system and the initial estimates of formation constants are not far from the true values, the iteration will converge in a finite number of cycles. The procedure is repeated for different chemical models and the best-fit model is selected basing on the statistical parameters. The potentiometric titration data obtained in the present investigation was subjected to analysis by Miniquad-75 program (Gans et al., 1976). This program is robust and uses both constrained least-squares and Marquardt methods to achieve convergence even in extreme cases of non-convergence. Species distribution diagrams for all the systems under study were generated using HySS (Alderighi et al., 1999) program. The data from different experiments with different metal to ligand ratios were refined separately using Miniquad-75 program to yield species relevant to that particular composition. This way of refinement has been found to be better (Braibanti et al., 1982) compared to analysing the combined data from all the titrations at a time since the main part of the error in the stability constants derives from the variability from one titration to another. Therefore, the authors processed the data from different compositions separately using Miniquad-75 program. The best-fit models were selected on the basis of $U$ (sum of the squares of residuals in mass balance equations), standard deviations in formation constants and other statistics like $x^{2}$ test which tests the distribution of errors against a normal one.

\section{RESULTS AND DISCUSSION}

\section{Proton Ligand Equilibria of Nicotinaldehyde Thiosemicarbazone (NTSC)}

A perusal of potentiometric titration data of NTSC indicates association of protons in the lower $\mathrm{pH}$ region and dissociation at higher $\mathrm{pH}$. Figure 1 shows the protonation and deprotonation equilibria of NTSC. The best fit model obtained using Miniquad-75 program shown in Table 1 contained two stability constants $\beta_{011}$ and $\beta_{012}$ corresponding to the formation of $\mathrm{LH}^{+}$and $\mathrm{H}_{2} \mathrm{~L}^{2+}$ 


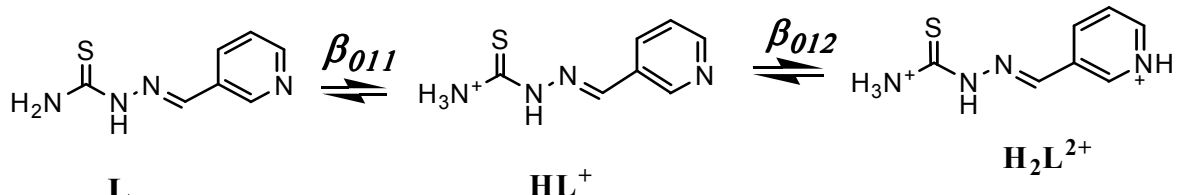

Figure 1: Proton-ligand equilibria of NTSC

Figure 2 shows the speciation of NTSC in its three forms from $\mathrm{pH} 2.4$ to $\mathrm{pH} 11$. At $\mathrm{pH} 11$, about $24.2 \%$ of the ligand was in $\mathrm{LH}$ form, and about $90.5 \%$ was in $\mathrm{L}$ form. At $\mathrm{pH}$ 's above $\mathrm{pH} 8.95$, the most predominant species was L. Between pH 8.95 and $\mathrm{pH}$ 3.02, the most predominant species was $\mathrm{LH}$. $\mathrm{LH}_{2}$ was the most predominant species at $\mathrm{pH}$ 's below $\mathrm{pH}$ 3.02. At $\mathrm{pH}$ $2.61,98.6 \%$ of the ligand is $\mathrm{LH}_{2}$, the other only 0.4 was LH.

Table 1: Protonation constants of NTSC (nicotinaldehyde thiosemicarbazone) in $1.15 \%(\mathrm{w} / \mathrm{v})$ SDS-water mixture at $30^{\circ} \mathrm{C}$ and ionic strength $0.1 \mathrm{M}(\mathrm{NaCl})$

\begin{tabular}{ccccccccc}
\hline \multicolumn{2}{c}{$\log \boldsymbol{\beta}_{\text {olh }}(\mathrm{SD})$} & $\mathbf{N p}$ & $\mathbf{U}_{\text {corr }}$ & $\mathbf{X}^{2}$ & Skewness & kurtosis & R-Factor & pH-Range \\
\hline $\boldsymbol{\beta}_{011}$ & $\boldsymbol{\beta}_{012}$ & & & & & & & \\
$10.47(1)$ & $14.90(2)$ & 85 & 6.03 & 10.21 & -0.22 & 3.5 & 0.01635 & $2.4-11.0$ \\
\hline
\end{tabular}

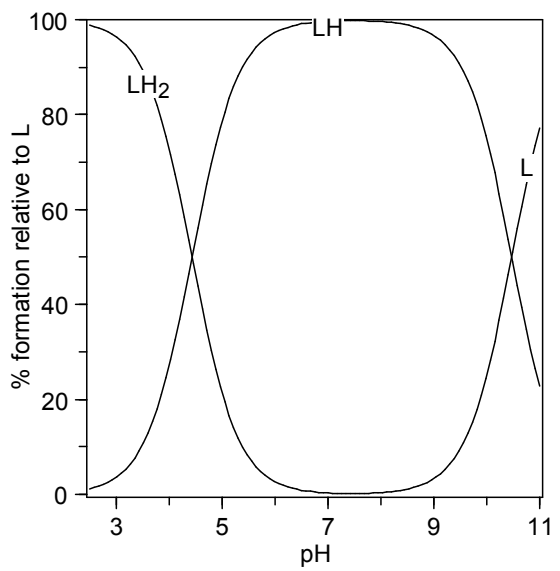

Figure 2: Distribution diagrams of protonated and deprotonated NTSC species in $1.15 \% \mathrm{w} / \mathrm{v}$ SDS-water mixture

\section{Metal-ligand Equilibria}

The solutions of ligand, and acid in the presence of metals were titrated with standard $\mathrm{NaOH}$ solution to determine the stability constants of complexes formed by $\mathrm{Mn}$ (II) and Ni (II) ions. The data obtained from metal ligand titrations was first subjected to analysis by classical procedures (Irving and Rossotti, 1953) to get the formation constants of simple mono-nuclear complexes $\mathrm{ML}$ and $\mathrm{ML}_{2}$. Simulated titration curves were then generated using a computer program SOPHD developed in our laboratory to see whether these species satisfy the experimental data. The simulated titration curves thus obtained were plotted along with the experimental ones to identify the regions of $\mathrm{pH}$ where they differ. Titration curves for all the compositions are shown in Figure 3 . The wide difference between the simulated and experimental curves reveals the presence of other major species in addition to simple mono-nuclear complexes. Different chemical models containing chemically plausible species depending on the nature of the ligand, metal and the $\mathrm{pH}$ region of difference in the curves were tested using the Miniquad-75 program. The required initial estimates of the formation constants were calculated basing on the formation constants of simple complexes and protonation/ deprotonation constants of the ligand.

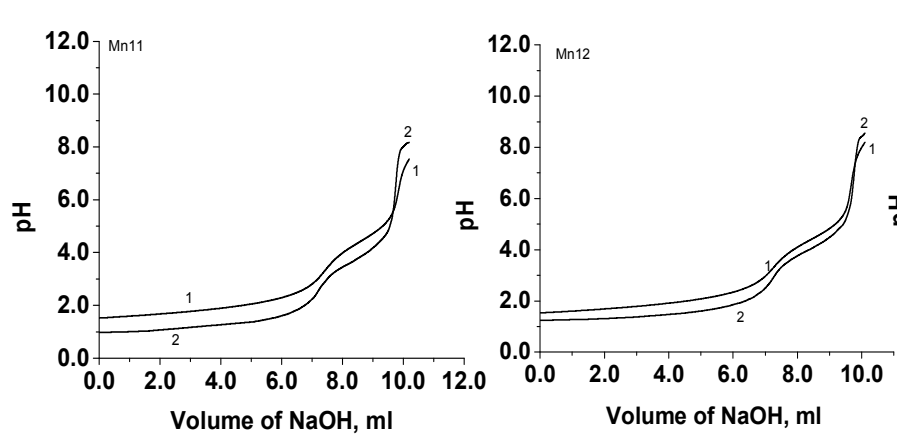

a)

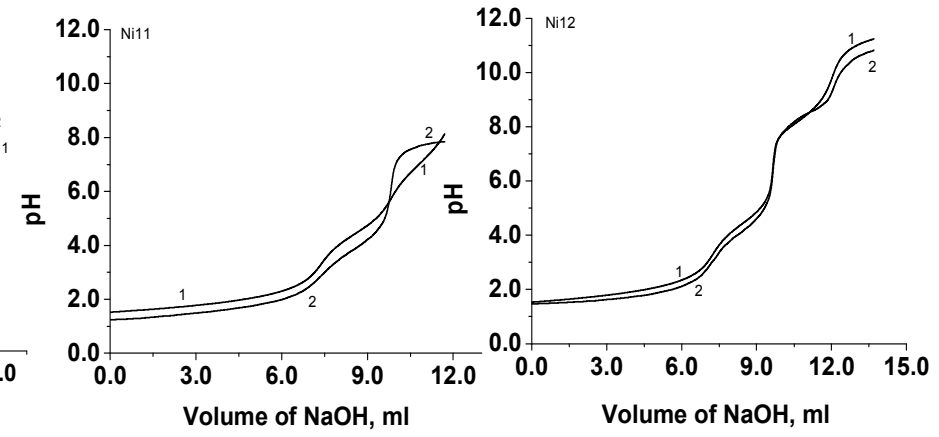

(b)

Figure 3: Simulated and experimental titration curves for (a) Mn (II)-NTSC and (b) nickel (II)- NTSC systems for 1:1 and 1:2 (1.Simulated titration curve 2. Experimental titration curve) respectively 


\section{Dunkana Negussa and Satyanarayana}

Various chemical models including all the plausible species $\mathrm{ML}, \mathrm{MLH}, \mathrm{ML}_{2}, \mathrm{ML}_{2} \mathrm{H}, \mathrm{ML}_{2} \mathrm{H}_{2}, \mathrm{MLH}_{-1}$, and $\mathrm{MLH}_{-2}$, were tested using Miniquad-75 program. The best-fit models thus obtained for metal-NTSC is presented in Table 2. The investigation revealed that the best-fit models $\mathrm{ML}$ and $\mathrm{MLH}$ for $1: 1$ ratio ; $\mathrm{ML}_{2}, \mathrm{ML}_{2} \mathrm{H}$, and $\mathrm{ML}_{2} \mathrm{H}_{2}$ for 1:2 ratio species between the ligand and $\mathrm{Mn}(\mathrm{II})$ and $\mathrm{Ni}(\mathrm{II})$ ions are formed depending on $\mathrm{pH}$. The formation constants are in good agreement with Irving-Williams order(Irving and Rossotti, 1953; Irving and Williams, 1948) i.e. $\mathrm{Mn}^{\text {II }}<\mathrm{Ni}^{\mathrm{II}}$.

The species distribution diagrams for metal-ligand systems (Fig.4) gives the concentration of formation of various species as a function of $\mathrm{pH}$. Nicotinaldehyde thiosemicarbazone has two associable protons and one dissociable proton from tautomerization of thione. The different forms of NTSC are, $\mathrm{H}_{2} \mathrm{~L}^{2+}, \mathrm{LH}^{+}$and $\mathrm{L}$ in the $\mathrm{pH}$ ranges below 2.5-6.0, 3.5-11.0 and above 9.0, respectively. The plausible binary metal-ligand complexes were predicted from the protonation data. The present investigation reveals the existence of $\mathrm{ML}, \mathrm{MLH}, \mathrm{ML}_{2} \mathrm{H}$, $\mathrm{ML}_{2}$, and $\mathrm{ML}_{2} \mathrm{H}_{2}$, for both $\mathrm{Mn}(\mathrm{II})$ and $\mathrm{Ni}(\mathrm{II})$.Charges of complex compounds are omitted for simplicity unless otherwise.

The typical species distribution diagrams of metal ligand complexes of various systems are shown in Figure 4 which indicates the formation of NTSC complexes of Mn (II) and $\mathrm{Ni}$ (II) in the $\mathrm{pH}$ ranges 2.5-11.0, and 2.6-10.0 respectively. The protonated species $M L H$ and $\mathrm{ML}_{2} \mathrm{H}_{2}$ are formed at low $\mathrm{pH}$ and $\mathrm{ML}_{2} \mathrm{H}$ is formed at higher $\mathrm{pH}$ for both $\mathrm{Mn}$ (II) and $\mathrm{Ni}$ (II). ML species for both metals is formed at higher $\mathrm{pH}$. The formations of various nicotinaldehyde thiosemicarbazone complex species are shown in the following equilibria:
Sci. Technol. Arts Res. J., Jan-March 2015, 4(1): 74-79

$$
\begin{aligned}
& M(I I)+\mathrm{LH}_{2}^{+} \rightleftharpoons M L H^{2+}+\mathrm{H}^{+} \\
& M(I I)+2 L_{2}^{+} \rightleftharpoons M L_{2} H_{2}^{2+}+2 H^{+} \\
& M(I I)+2 L H \rightleftharpoons M L_{2} H^{+}+H^{+} \\
& M L H^{2+} \\
& M(I I)+2 L H \\
& M L_{2} \mathrm{H}_{2}^{+} \\
& M L_{2} H^{+}
\end{aligned}
$$

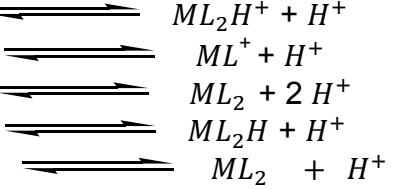

The typical distribution curves of species in binary mixtures are shown in Figure 4. The most important features of distribution diagrams are the $\mathrm{pH}$ limit of evolving and disappearance of compounds. At low $\mathrm{pH}$ the protonated species $\mathrm{MLH}, \mathrm{ML}_{2} \mathrm{H}$ and $\mathrm{ML}_{2} \mathrm{H}_{2}$ are prevalent and predominant from $\mathrm{pH}=2.5$ to $\mathrm{pH}=8.0$ for both $1: 1$ and $1: 2$ ratios. Beyond $\mathrm{pH}=7.0$ the non-protonated $\mathrm{ML}$, and $\mathrm{ML}_{2}$ complexes appear. The main metal species in both systems are $\mathrm{ML}, \mathrm{MLH}, \mathrm{ML}_{2} \mathrm{H}, \mathrm{ML}_{2} \mathrm{H}_{2}$. $\mathrm{MLH}$ is observed as a main species in acidic region which is gradually converted to $\mathrm{ML}$, and $\mathrm{ML}_{2}$ by increasing the solution $\mathrm{pH}$.

A series of complex equilibria may be responsible for producing the $\mathrm{ML}_{2} \mathrm{H}$ and $\mathrm{MLH}$ complexes. Simultaneous collision of $\mathrm{M}$, and $\mathrm{LH}$ and decomposition of $\mathrm{ML}_{2} \mathrm{H}_{2}$ at $\mathrm{pH}$ about 6. whereas, the MLH is probably produced by combination of $\mathrm{M}$ and $\mathrm{LH}_{2}$ followed by a fast deprotonation at $\mathrm{pH}$ below 6 . This suggested that the formation pattern could be supported from the sharp descending of $\mathrm{LH}_{2}$ concentration in the $2.5-6.0 \mathrm{pH}$ region. In $1: 1$ ratio in the basic region $\mathrm{ML}$ was the only predominant species for both metal ions and a similar

\begin{tabular}{|c|c|c|c|c|c|c|c|c|c|c|}
\hline Metal & \multicolumn{2}{|c|}{$\log \beta_{m / h}(S D)$} & & $\mathrm{Np}$ & $\mathbf{U}_{\text {corr }}$ & $\mathrm{x}^{2}$ & Skewness & Kurtosis & R-Factor & pH-Range \\
\hline & & & & $1: 1$ & & & & & & \\
\hline & 110 & 111 & ------ & & & & & & & \\
\hline $\mathrm{Mn}(\mathrm{II})$ & $4.32(5)$ & $13.20(2)$ & ----- & 28 & 1.27 & 30.48 & 0.13 & 4.40 & 0.00661 & $2.5-10.0$ \\
\hline \multirow[t]{3}{*}{$\mathrm{Ni}(\mathrm{II})$} & $5.63(4)$ & $13.22(5)$ & ------- & 41 & 9.4 & 81.42 & 0.61 & 7.53 & 0.01886 & $2.5-9.0$ \\
\hline & & & & 1:2 & & & & & & \\
\hline & 120 & 121 & 122 & & & & & & & \\
\hline $\mathrm{Mn}(\mathrm{II})$ & $7.85(5)$ & $16.88(5)$ & $24.14(7)$ & 25 & 0.76 & 28.57 & -0.64 & 4.55 & 0.00575 & $2.5-11.0$ \\
\hline $\mathrm{Ni}(\mathrm{II})$ & $8.98(2)$ & $17.25(5)$ & $24.82(8)$ & 46 & 0.38 & 43.10 & -0.12 & 4.21 & 0.00438 & $2.8-10.0$ \\
\hline
\end{tabular}
pattern is observed in 1:2 system wherein, the $\mathrm{ML}_{2}$ species becomes the main species in basic region (Fig. 4 $\mathrm{B} \& \mathrm{D})$. For both ratios in the physiological $\mathrm{pH}$ range the protonated species are the predominant ones.

Table 2: Parameters of best-fit chemical models of NTSC complexes of Mn (II) and Ni (II) in SDS-water mixtures (1.15\% $\mathrm{w} / \mathrm{v})\left(\right.$ Temperature $=303 \mathrm{~K}$, ionic strength $\left.=0.10 \mathrm{~mol} \mathrm{~L}^{-1}\right)$

$\mathrm{U}_{\text {corr }}=\mathrm{U} \times 10^{-8} / \mathrm{NP}-\mathrm{m} ; \mathrm{NP}=$ number of points; $\mathrm{m}=$ number of species; $\mathrm{SD}=$ standard deviation
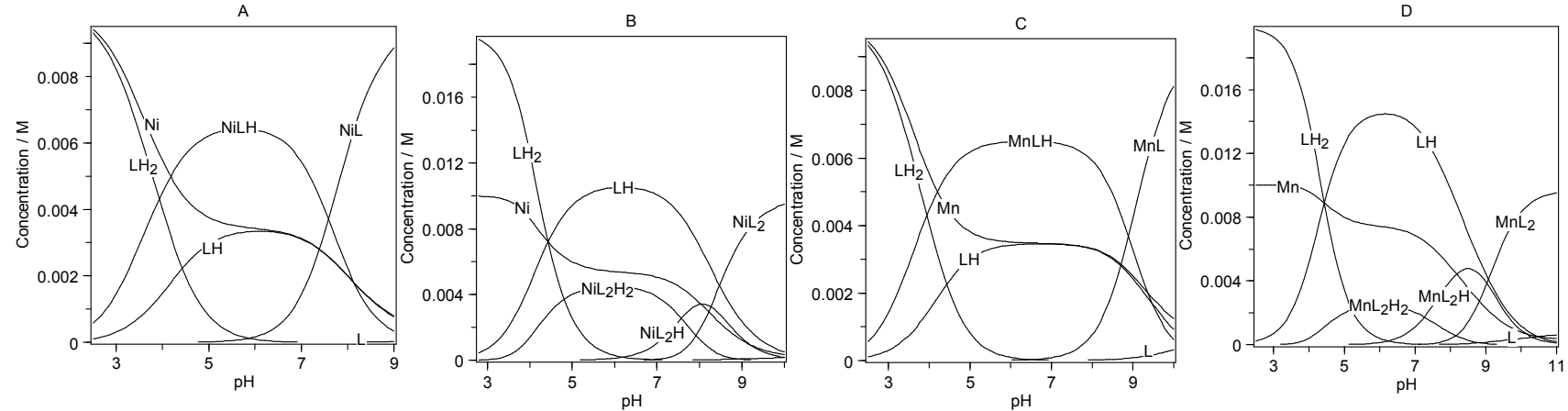

Figure 4: Distribution diagram of NTSC-Metal complexes in $1.15 \%(w / v)$ SDS-water mixture. (A) \& (B) are $1: 1 \& 1: 2$ ratios for $\mathrm{Ni}(\mathrm{II})$ and $(\mathrm{C}) \&(\mathrm{D})$ graphs are 1:1 \&1:2 ratios for $\mathrm{Mn}(\mathrm{II})$ complexes. 


\section{Dunkana Negussa and Satyanarayana}

\section{Effect of Systematic Errors on Best Fit Model}

Error in the concentrations of alkali, mineral acid, metal and ligand affects the magnitudes of stability constants. Such parameters are said to be influential parameters. Since there is no way to directly study the effect of systematic errors in the influential parameters on the magnitude of stability constant in MINIQUAD75, the best to do is provision of pessimistic errors in the concentrations of mineral acid, alkali, ligand, and metal.

Table 3: Effect of errors in influential parameters on $\mathrm{Mn}$ (II)-NTSC complex stability constants in SDSwater mixture $(1.15 \% \mathrm{w} / \mathrm{v})$

\begin{tabular}{cccc}
\hline \multirow{2}{*}{ Ingredient } & \multirow{2}{*}{ \% Error } & \multicolumn{2}{c}{$\log \boldsymbol{\beta}_{\boldsymbol{m} \mathbf{h}}(\mathrm{SD})$} \\
\cline { 2 - 4 } & & $\mathbf{1 1 0}$ & $\mathbf{1 1 1}$ \\
\hline \multirow{4}{*}{ Acid } & 0 & $4.32(5)$ & $13.20(2)$ \\
\hline \multirow{4}{*}{ Alkali } & -5 & $5.15(8)$ & $14.05(3)$ \\
& -2 & rejected & $13.83(3)$ \\
& +2 & $3.64(49)$ & $13.49(3)$ \\
& +5 & rejected & $13.16(8)$ \\
\hline \multirow{4}{*}{ Ligand } & -5 & rejected & $11.12(88)$ \\
& -2 & rejected & $13.37(7)$ \\
& +2 & $5.06(7)$ & $14.02(3)$ \\
& +5 & $5.67(13)$ & $14.31(8)$ \\
\hline \multirow{4}{*}{ Metal } & -5 & $4.34(6)$ & $13.63(1)$ \\
& -2 & $4.38(6)$ & $13.69(1)$ \\
& +2 & $4.42(7)$ & $13.77(3)$ \\
& +5 & $4.46(7)$ & $13.83(2)$ \\
\hline & -5 & $4.42(7)$ & $13.75(2)$ \\
& -2 & $4.41(7)$ & $13.73(2)$ \\
& +2 & $4.36(6)$ & $13.70(1)$ \\
& +5 & $4.34(6)$ & $13.68(1)$ \\
\hline
\end{tabular}

This may help to critically evaluate the best fit model because the data acquisition was done under varied experimental conditions with different accuracies. The results of a typical system given in Table 3 emphasize
Sci. Technol. Arts Res. J., Jan-March 2015, 4(1): 74-79

that the order of the ingredients that influence the magnitudes of stability constants due to incorporation of errors is alkali > acid > ligand > metal. As seen from the results in the table species are even rejected when errors are introduced in the concentrations of the alkali and acid. The rejection of species and increased standard deviations in the stability constants on introduction of errors confirm the appropriateness of the experimental conditions (like concentrations) and the choice of the best fit models.

\section{Structures of Complexes}

As depicted from structural studies, most thiosemicarbazone ligands coordinate through oxygen, nitrogen and sulfur donor atoms in their $(\mathrm{N}, \mathrm{S})$ bidentate form or $(\mathrm{N}, \mathrm{N}, \mathrm{S}$ or $\mathrm{O}, \mathrm{N}, \mathrm{S})$ tridentate form, to form metallic complexes of varied molecular geometry (Pal et al., 2002; Bakkar et al., 2003; El-Shazly et al., 2006; Rios and Valcarcel, 1985; Hans Stiinzi, 1981). Thus, Nicotinaldehyde thiosemicarbazone is expected to coordinate as $(\mathrm{N}, \mathrm{S})$ bidentate form to produce metallic complexes with transition metal ions with distinct molecular geometry. Mono-and bis- NTSC complexes have been identified for M (II)-NTSC systems of the transition metal ions. Even though NTSC has five potential donor sites, the structural studies show thiosemicarbazones coordinate through the azomethine nitrogen and sulfur of thiol. Therefore, in the complexes of $\mathrm{Mn}(\mathrm{II})$ and $\mathrm{Ni}(\mathrm{II})-\mathrm{NTSC}$ for protonated complexes the protons can likely be ascribed to the non-coordinating hydrazinic nitrogen atom and pyridine moiety and coordination occurs through azomethine nitrogen and thiolate sulfur donor set $\left(\mathrm{N}, \mathrm{S}^{-}\right)$. The simple species $\mathrm{ML}_{2}$ assumedly contain ligands coordinated to $\mathrm{Ni}$ (II) and $\mathrm{Mn}$ (II) through azomethine nitrogen and thiolate sulfur donor atoms as illustrated in Figure 5. Hence, octahedral structures are proposed for the complexes of $\mathrm{Ni}$ (II) and Mn (II) with NTSC.<smiles></smiles><smiles></smiles><smiles>NC1=NN(c2cccnc2)C2(S1)SC(N)=NN2c1cccnc1</smiles><smiles></smiles><smiles></smiles>

Figure 4: Proposed Structures of M (II) - NTSC complexes of Ni (II) and Mn (II)

\section{CONCLUSIONS}

In the present work, $\mathrm{pH}$-potentiometric speciation study was performed to determine protonation constant of ligand and stability constant of complex to assess binary species for NTSC with $\mathrm{Mn}$ (II) and Ni (II) metal ions in $1.15 \%(\mathrm{w} / \mathrm{v})$ SDS-water mixture. The common species formed are $M L, M L H$ for $1: 1$ ratio and $M_{2} \mathrm{H}, \mathrm{ML}_{2} \mathrm{H}_{2}$ and $\mathrm{ML}_{2}$ for $1: 2$ ratio for both metals. Compared to $\mathrm{Mn}$ (II), Ni (II) forms similar but more stable complexes as expected. At the physiological $\mathrm{pH}$ range the $\mathrm{ML}_{2} \mathrm{H}$ complex is charge neutral which enables an easier passage across the cell membrane. It was also concluded that the formation of protonated complexes is favorable with both metals in the physiological $\mathrm{pH}$ range. The order of ingredients influencing the magnitudes of stability constants due to intentional incorporation of errors in their concentrations is alkali> acid $>$ ligand $>$ metal.

\section{Conflict of Interest}

Conflict of interest none declared.

\section{REFERENCES}

Alderighi, L., Gans, P., lenco, A., Peters, D., Sabatini, A., Vacca, A. (1999). Hyperquad simulation and speciation (HySS): a utility program for the investigation of equilibria involving soluble and partially soluble species. Coordination Chemistry Review 184: 311-318. 


\section{Dunkana Negussa and Satyanarayana}

Baes Jr. C.F. and Mesmer, R.E. (1976) The hydrolysis of cations. Oak Ridge National Laboratory.

Bakkar, M.S., Siddiqi, M.Y. and Monshi, M.S. (2003). Preparation and investigation of the bonding mode in the complexes of $\mathrm{Pt}(\mathrm{II})$ with thiosemicarbazone ligands. Synthesis and Reactivity in Inorganic, Metal-Organic, and Nano-Metal Chemistry 33(7): 1157-1169.

Belicchi-Ferrari, M., Bisceglie, F., Casoli, C., Durot, S., Morgenstern-Badarau I., Pelosi,G., Pilotti, E., Pinelli, S., Tarasconi, P. (2005). Copper(II) and Cobalt(III) Pyridoxal Thiosemicarbazone Complexes with Nitroprusside as Counterion: Syntheses, Electronic Properties, and Antileukemic Activity. Journal of Medicinal Chemistry 48(5): 1671-1675.

Beraldo, H. and Gambino, D. (2004). The wide pharmacological versatility of semicarbazones, thiosemicarbazones and their metal complexes. MiniReviews in Medicinal Chemistry 4: 31-39.

Birca, M., Tapcov,V., Prisacari, V., Gulea, A., Buraciova, S. (2004). Synthesis and antimicrobial properties of $\mathrm{Cu}$ complexes with thiosemicarbazones of substituted salicylic aldehydes. COFrRoCA 2004, Actes du Colloque Franco-Roumain de Chimie Applique, $3^{\text {rd }}$ Bacau, Romania, sept. 22-26, 44-45 (Fr). Rome. ISBN: 9738392-36-5.

Birk, J.P. (1970). Mechanism of the Reduction of Vanadium(V) by Hexacyanoferrate(II) in Acidic Aqueous Solution. Inorganic Chemistry 9: 125.

Braibanti, A., Dallawali, F., Mori, G. and Vigonl, B. (1982). Analysis of variance applied to determinations of equilibrium constants Talanta 29: 725-731.

Brockman, R.W., Sidwell, R.W., Arnett, G., and Shaddix, S. (1970). Heterocyclic thiosemicarbazones: correlation between structure, inhibition of ribonucleotide reductase, and inhibition of DNA viruses. Proceedings of the Society for Experimental Biology and Medicine 133:609-614.

Chandra, S. and Kumar, A. (2007). Spectral, IR and magnetic studies of $\mathrm{Mn}(\mathrm{II}), \mathrm{Co}(\mathrm{II}), \mathrm{Ni}(\mathrm{II})$ and $\mathrm{Cu}(\mathrm{II})$ complexes with pyrrole-2-carboxyaldehyde thiosemicarbazone Spectrochimica Acta Part A 68: 469-473

El-Shazly, R.M., Al-Hazmi, G.A.A., Ghazy, S.E., El-Shahawi, M.S. and El-Asmy, A.A. (2006). Synthesis and spectroscopic characterization of cobalt(II) thiosem icarbazone complexes. Journal of Coordination Chemistry 59(8): 845-859.

Enyedy, E.A.., Nagy, N.V., Zsigó, É., Kowol, C.R. , Arion,V. B., Keppler, B.K., and Kiss, T. (2010). Comparative Solution Equilibrium Study of the Interactions of Copper(II), Iron(II) and Zinc(II) with Triapine (3Aminopyridine-2-carbaldehyde Thiosemicarbazone) and Related Ligands. European Journal of Inorganic Chemistry 1717-1728.

Enyedy, E.A., Primik, M.F., Kowol,C.R., Arion,V.B., Kiss, T. and Keppler, B.K. (2011). Interaction of Triapine and related thiosemicarbazones with iron(III)/(II) andgallium (III): a comparative solution equilibrium study. Dalton Transaction 40: 5895

Gans, P., Sabatini, A. and Vacca, A. (1976). An Improved Computer Program for the Computation of Formation Constants from Potentiometric Data. Inorganica Chimica Acta 18: 237-239.

Gran, G. (1988). Equivalence volumes in potentiometric titrations. Analytica Chimica Acta 206: 111-123.

Grunberg, E. and Leiwant, B. (1951). Anti-Tubercular Activity in vivo of Nicotinaldehyde Thiosemicarbazone and Its
Sci. Technol. Arts Res. J., Jan-March 2015, 4(1): 74-79

Isomers. Proceedings of the Society for Experimental Biology and Medicine 77:47-50.

Gulea, A., Poirier, D., Roy, J., Spinu, S., Coziri, N., Birca, M., Tapcov, V. (2004). Anticancer effect of sulfanilamide complexes of $\mathrm{Cu}(\mathrm{II})$ with thiosemicarbazones of substituted salicylic aldehydes. COF-rRoCA 2004, Actes du Colloque Franco-Roumain de Chimie Applique, 3rd Bacau, Romania, Sept.22-26, 68(Fr). Rom. ISBN: 9738392-36-5.

Hall, I.H., Lackey, C.B., Kistler, T.D. (2000). Cytotoxicity of copper and cobalt complexes of furfural semicarbazone and thiosemicarbazone derivatives in murine and human tumor cell lines. Pharmazie 55: 937-941.

Irving, H.M., Rossotti, H.S. (1953). Methods for Computing Successive Stability Constants from Experimental Formation Curves. Journal of the Chemical Society 33973405.

Irving, H.M., Rossotti, H.S. (1954). The Calculation of Formation Curves of Metal Complexes from pH-Titration Curves in Mixed Solvents. Journal of the Chemical Society 2904-2910

Irving, H.M. and Williams, R.J.P. (1948). Order of Stability of Metal Complexes. Nature (London) 162: 746-7.

John, R.P., Sreekanth, A., Rajakannan, V., Ajith, T.A., Kurup, M.R.P. (2004). New copper (II) complexes thiosemicarbazones and polypyridyl co-ligands: structural, electrochemical of 2-hydroxyacetophenone $N$ (4)substituted and antimicrobial studies. Polyhedron 23: 2549-2559.

Liberta, A. E., West, D. X. ( 1992). Antifungal and antitumor activity of heterocyclic thiosemicarbazones and their metal complexes: current status. BioMetals 5(2):121-126.

Ludwig, J.A., Szakács, G., Martin, S.E. (2006). Selective toxicity of NSC73306 in MDR1-positive cells as a new strategy to circumvent multi drug resistance in cancer. Cancer Research 66: 4808-15.

Pal, I., Basuli, F., and Bhattacharya, S. (2002). Thiosemicarbazone complexes of the platinum metals. A story of variable coordination modes. Proceedings of the Indian Academy of Sciences: Chemical Sciences114(4):255-68.

Pelosi, G. (2010). Thiosemicarbazone Metal Complexes: From Structure to Activity. Open Crystallography Journal 3: $16-28$.

Rios, A. and Valcarcel, M. (1985). Simultaneous kinetic determination of copper, cobalt and nickel by means of group interchange reactions. Talanta 32(9): 851-858.

Shao, J., Zhou, B., Di Bilio, A.J. (2006). A Ferrous-Triapine complex mediates formation of reactive oxygen species that inactivate human ribonucleotide reductase. Molecular Cancer Therapy 5: 586-592.

Stiinzi, H. (1981). Copper Complexation by Isatin $\beta$ Thiosemicarbazones in Aqueous Solution. Australian Journal of Chemistry 34: 2549-2561.

Williams, D.R.( 1972). Metals, ligands and cancer. Chemical Review 72: 203-213.

Wu, C., Shukla, S., Calcagno, A.M., Hall, M.D., Gottesman, M.M. and Ambudkar, S.V. (2007). Evidence for dual mode of action of a thiosemicarbazone, NSC73306: a potent substrate of the multidrug resistance linked $A B C G 2$ transporter. Molecular Cancer Therapy 6: 3287-3289.

Yuan, J., Lovejoy, D.B. and Richardson, D.R., (2004). Novel di-2-pyridyl-derivediron chelators with marked and selective antitumor activity: in vitro and in vivo assessment. Blood 104: 1450-1458. 